Crop Breeding and Applied Biotechnology 13: 172-177 2013

Brazilian Society of Plant Breeding. Printed in Brazil

\title{
ARTICLE
}

\section{Selection of carioca common bean progenies resistant to white mold}

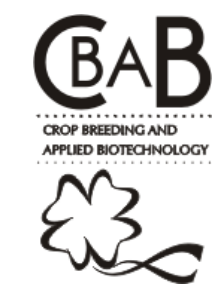

\author{
Renato Sérgio Batista Carvalho ${ }^{1 *}$, Igor Almeida Lima ${ }^{2}$, Filipe Couto Alves ${ }^{2}$ and João Bosco dos Santos ${ }^{2}$
}

Received 30 October 2012

Accepted 06 September 2013

\begin{abstract}
A backcross breeding program between commercial common bean cultivars (VC3 and M20) and sources of resistance (Ex-Rico 23 and G122) was conducted with a view toward selecting carioca (beige with brown stripes) progenies resistant to white mold. Forty-eight progenies $\left(27 F_{2: 6} B C_{1}\right.$ and $\left.21 F_{1.5} B C_{2}\right)$ were evaluated for yield, growth habit, grain type and pathogen response by two methodologies for assessment ("straw test" and "oxalic acid"). The methods were effective in discriminating the progenies, showing differing results, for they may assess different resistance mechanisms. Thus, they should be used together. Simultaneous selection for yield, growth habit, grain type and white mold resistance proved to be viable. The most appropriate strategy was to use lower intensities of selection and prioritize traits such as resistance and grain type, which are essential for commercial acceptance. Two progenies proved their superiority for the breeding program for they combine the traits of resistance and favorable grain type.
\end{abstract}

Key words: Sclerotinia sclerotiorum, Straw test, Oxalic acid, Phaseolus vulgaris.

\section{INTRODUCTION}

Common bean (Phaseolus vulgaris L.) is one of the staple foods of the Brazilian diet. Nevertheless, white mold (Sclerotinia sclerotiorum (Lib.) de Bary) is a pathogen that affects the crop, especially in crop areas irrigated with a center pivot in successive crop seasons, and it may lead to annual losses in excess of 50\% (Oliveira 2005, Soule et al. 2011).

White mold is controlled by physiological resistance mechanisms and by escape mechanisms, such as a bushy growth habit of the plant, resulting in a more aerated microenvironment. Nevertheless, the two types of mechanisms are not sufficient for control of the disease (Kim et al. 2000, Kolkman and Kelly 2002, Huang et al. 2003, Soule et al. 2011). These mechanisms are found mainly in unadapted sources of resistance and may be incorporated in commercial cultivars by means of backcrosses.

There is evidence that resistance to white mold is characterized as horizontal resistance, resulting from the accumulation of effects of diverse genes, involving various mechanisms of resistance (Antonio et al. 2008, Soule et al. 2011). Among the methodologies most used for assessment of the disease are artificial inoculation in the field by the straw test method and the oxalic acid indirect absorption method (Petzoldt and Dickson 1996, Kolkman and Kelly 2000).
Given the complexity of resistance to white mold, the study was performed for the purpose of assessing, by different methodologies, the reaction of the progenies derived from backcrosses of sources of resistance, and selecting progenies for resistance, growth habit, yield and grain type.

\section{MATERIAL AND METHODS}

The experiments were conducted at the Universidade Federal de Lavras (UFLA), Lavras, MG, Brazil. In the winter 2009 crop season, sowing occurred in the first half of August in a greenhouse. In the dry seasons, sowing occurred in February and, in winter 2010, sowing occurred in the first half of August, both in the field. The progenies used in the experiments were obtained from three backcross populations: [M(M x G122)], [M(M x Ex Rico 23)] and $\{$ M20[M20(M20 x G122)]\}. The cultivar BRSMG Madrepérola (M) was developed by the Universidade Federal de Viçosa. It has carioca (beige with brown stripes) grain type, high yied, type III growth habit and resistance to some races of Colletotrichum lindemuthianum. The M20 line was developed by the Universidade Federal de Lavras, has carioca grain type and type II growth habit, and is resistant to all the races of $C$. lindemuthianum which occur in Brazil because it carries the pyramid of alleles of $\mathrm{Co}-4^{2}, \mathrm{Co}-5$ and Co-7 (Silva et al. 2006), and it provides resistance to angular

\footnotetext{
${ }^{1}$ Universidade de São Paulo (USP), Escola Superior de Agricultura Luiz de Queiroz (ESALQ), Departamento de Genética, 13.418-900, Piracicaba, SP, Brazil. *E-mail: rsbcarvalho@hotmail.com

${ }^{2}$ Universidade Federal de Lavras (UFLA), Departamento de Genética, 37.200-000, Lavras, MG, Brazil
} 
leaf spot, coming from the Andean line Jalo EEP 558. The G122 line is of Andean origin and has type I growth habit and large seeds with a cream-colored background and red spots. The Ex Rico 23 line is of Mesoamerican origin and has type II growth habit and small white grain. Lines G122 and Ex Rico 23 are physiological sources of resistance to white mold (Miklas et al. 2001, Kolkman and Kelly 2003).

Among the 48 evaluated progenies, $27 \mathrm{~F}_{2: 6}$ progenies were derived from the $\mathrm{BC}_{1}$ of the backcrosses $[\mathrm{M}(\mathrm{M} \mathrm{x}$ $\mathrm{G} 122)]$ and $\left[\mathrm{M}\left(\mathrm{M} x\right.\right.$ Ex Rico 23)] and, $21 \mathrm{~F}_{1: 5}$ were derived from the $\mathrm{BC}_{2}$ of the backcross $\{\mathrm{M} 20[\mathrm{M} 20(\mathrm{M} 20 \times \mathrm{G} 122)\}$ plus the control lines M20 and G122.

Reaction to white mold was assessed by measurement of oxalic acid absorption (Kolkman and Kelly 2000) in the winter 2009 crop season, using a completely randomized design with three replications, with 10 plants representing a plot. Assessment was carried out in four steps, due to the large number of genotypes. Each step consisted of assessment of 12 genotypes and two controls, M20 (susceptible) and G122 (resistant), which were maintained as common genotypes in the following steps with the other progenies. The seeds were sown in Styrofoam trays using a commercial substrate and kept in a greenhouse until the V3 stage. The plants were then cut at the base of the stem and fastened to small sheets of Styrofoam with the aid of foam strips. The sheets of Styrofoam were arranged on the surface of a tray containing an oxalic acid solution $(20 \mathrm{mM}$, previously adjusted to $\mathrm{pH} 4.0$ with $\mathrm{NaOH}$ ), immersing the base of the stem around $2 \mathrm{~cm}$ in the solution. Assessment was performed for symptoms of wilting from 15 to 20 hours after exposure to the oxalic acid solution, using the descriptive scale proposed by Kolkman and Kelly (2000), with the score of "1" being attributed to plants without symptoms of wilting and the score of " 6 " being attributed to completely wilted plants.

For assessment of the reaction to white mold by the straw test methodology, two experiments were performed, one in the dry period and the other in the winter 2010 period. The experiments were set up using the 48 selected progenies and the $\mathrm{M} 20$ control in a $7 \times 7$ lattice with three replications, with a one-meter length row representing a plot, inoculating 10 plants per plot. Sowing was performed in the field with between-row spacing of $50 \mathrm{~cm}$ and sowing density of 15 seeds per linear meter. Fertilization was performed at planting with $300 \mathrm{~kg} \mathrm{ha}^{-1}$ of the formula 8-28-16 $\left(\mathrm{N}_{-} \mathrm{P}_{2} \mathrm{O}_{5}-\mathrm{K}_{2} 0\right)$ and later application of $150 \mathrm{~kg} \mathrm{ha}^{-1}$ of ammonium sulfate in top dressing at around twenty days after plant emergence. Spray irrigation was carried out whenever necessary up to the time of inoculation.

Four weeks after sowing, the progenies were inoculated with white mold, obtained from sclerotia collected in a contaminated area of a common bean crop grown under center pivot irrigation in the county of Ijaci in the south of MG. The fungus was cultured in a PDA medium in Petri dishes for three days at $23^{\circ} \mathrm{C}$. The mycelium used was the second generation derived from chopping up the sclerotium. Adapting the methodology described by Petzold and Dickson (1996), tips of the Eppendorf micropipette were used during inoculation to perforate the agar containing the mycelium of the fungus. The apex of the main stem of the plant was cut around $2.5 \mathrm{~cm}$ from the node, where the tip containing the mycelium of the fungus was inserted.

In the experiment conducted in the 2010 dry season, after inoculation, spray irrigation was carried out, with approximate flow of $10 \mathrm{~mm} \mathrm{~h}^{-1}$ twice a day for 30 minutes, seeking to create ideal conditions for development of the pathogen. Assessment was performed 15 days after inoculation. As for the experiment conducted in the winter 2010 season, spray irrigation was used (approximately $10 \mathrm{~mm} \mathrm{~h}^{-1}$ ), with a duration of 2 hours and interval of approximately 72 hours, seeking to simulate normal crop conditions. Assessment occurred eight days after inoculation. Both experiments were evaluated by means of a diagrammatic scale (Kolkman and Kelly 2000, Singh et al. 2007) with scores ranging from "1" for plants without symptoms to 9 for plants that exhibited stem rotting beyond the third internode from the point of inoculation.

For assessment of the agronomic traits, the progenies were sown in the first half of August 2009 and 2010 in the triple lattice $7 \times 7$ design, with 48 progenies and the M20 control being assessed. In the winter 2009 experiment, the plots consisted of a one-meter row while in the winter 2010 experiment, the plots consisted of three two-meter rows. Normal crop treatments were carried out. Grain yield was measured in $\mathrm{g} / \mathrm{plot}$, with later extrapolation to $\mathrm{kg} \mathrm{ha}^{-1}$. The growth habit trait of the plant was assessed by means of a descriptive scale similar to that of Collicchio et al. (1997), with scores ranging from " 1 " (growth habit II, upright plant, with upright stem and high first pod height) to "9" (growth habit III, plant with great distance between nodes and completely prostrate).

For the grain type trait, the carioca type was taken as a standard using the descriptive scale proposed by Menezes Júnior et al. (2008), with scores ranging from " 1 " ("carioca type grains) to " 5 " (grains outside the carioca standard).

For ordering of the best progenies considering the various traits at the same time, rank sum was performed, according to the methodology proposed by Mulamba and Mock (1978). For grain yield, growth habit and grain type, the index was carried out using the adjusted mean values of the joint analyses for these traits in the winter 2009 and 2010 experiments. As for the trait of reaction to white mold by the straw test methodology, the adjusted mean value from 
joint analysis of the experiments with different levels of irrigation was used. In the same way, the mean values of the progenies and the M20 control were ordered for the trait of reaction to white mold by the oxalic acid absorption method.

Heritability, with its respective upper and lower limits (Knapp et al.1985), and selective accuracy () (Resende 2007) were estimated for each trait. Estimates of gain from selection were obtained individually for each trait and for the selection index by means of the expression presented by Ramalho et al. (2012).

The Pearson correlation coefficients between the mean values of the joint analyses (for yield, growth habit, grain type and straw test) and of the grouping analysis (oxalic acid) of the traits two by two were estimated for the purpose of verifying association between them.

\section{RESULTS AND DISCUSSION}

Summaries of the analyses of variance are shown in Tables 1 and 2. Due to the descriptive scales and diagrammatic scale identifying the most favorable phenotype with the lowest score and for the purpose of facilitating interpretation of the data, the mean values of the experiments were adjusted by inverting the scale so that the greatest value would always correspond to the favorable phenotype.

For assessment of reaction to white mold by oxalic acid, significant differences were observed between the progenies

Table 1. Analysis of variance of the reaction of common bean progenies to white mold assessed by two methodologies ("oxalic acid" and "straw test")

\begin{tabular}{lll}
\hline & Winter 2009 & \\
\cline { 2 - 3 } Oxalic acid & Sources of variation & MS \\
& Experiments & $1.1676^{* *}$ \\
& Progenies & $0.9683^{* *}$ \\
& Error & 0.1723 \\
\hline \multirow{4}{*}{ Straw test } & Joint Analysis & \\
\cline { 2 - 3 } & Sources of variation & MS \\
& Experiments (E) & $865.7968^{* *}$ \\
& Progenies (P) & $1.8718^{* *}$ \\
& Ex P & 0.5019 \\
\hline
\end{tabular}

"Significant at $5 \% ;{ }^{* *}$ Significant at $1 \%$ by the $\mathrm{F}$ test.
$(\mathrm{P}<0.01)$, as well as high values for selective accuracy and heritability (Table 3 ). Estimated heritability $(0.82)$ is in agreement with the heritabilities found by Antonio et al. (2008) and Kolkman and Kellly (2002), which oscillated from 0.30 to 0.82 . The significance found between experiments may be attributed to the environmental differences of the time periods in which each assessment was performed. According to Kolkman and Kelly (2000), temperature makes a significant contribution to expression of the trait and it is the most important environmental component in alteration of the reaction to the oxalate, justifying the inclusion of resistant and susceptible controls in each experiment. The mean coefficient of variation (Table 3 ) was less than the coefficients presented by Antonio et al. (2008), which ranged from $25 \%$ to $48 \%$. The selective accuracy found may be considered very high (Resende 2007). Such estimates indicate good experimental precision.

For the trait of reaction to white mold by the straw test methodology, analyses showed significant differences between progenies $(\mathrm{P}<0.01)$ in the two experiments assessed and in joint analysis of the experiments developed in the dry and winter crop seasons of 2010. There were also differences for the experiment source of variation, confirmed by the difference between the mean values of the two time periods assessed. This large difference may be attributed, in part, to the irrigation methodology used in each experiment. In the 2010 dry season experiment, both the daily irrigation and the assessment made at 15 days

Table 2. Joint analyses of variance for grain yield, plant growth habit and grain type of common bean progenies

\begin{tabular}{lll}
\hline Trait & Sources of variation & MS \\
\hline \multirow{3}{*}{ Yield } & Experiments (E) & $18955361.7^{* *}$ \\
& Progenies (P) & $1158275.9^{* *}$ \\
& E x P & $1761372.9^{* *}$ \\
\hline \multirow{3}{*}{ Growth habit } & Experiments (E) & 0.4116 \\
& Progenies (P) & $1.9736^{* *}$ \\
& E x P & 1.2449 \\
\hline \multirow{3}{*}{ Grain type } & Experiments (E) & 0.0233 \\
& Progenies (P) & $0.4245^{* *}$ \\
& E x P & $0.2195^{* *}$ \\
\hline
\end{tabular}

"Significant at $5 \%$; " Significant at $1 \%$ by the $\mathrm{F}$ test.

Table 3. Estimates of mean value, coefficients of variation $(\mathrm{CV} \%)$, selective accuracy $\left(\mathrm{r}_{\hat{\mathrm{g} g}}\right)$ and heritability $\left(\mathrm{h}^{2}\right)$ with their respective lower $(\mathrm{LL})$ and upper (UL) limits

\begin{tabular}{llllll}
\hline \multirow{2}{*}{ Trait } & Yield & Growth habit & Grain type & Straw test & Oxalic acid \\
\cline { 2 - 6 } & Joint analysis & Joint analysis & Joint analysis & Joint analysis & Winter 2010 \\
\hline Mean $\left(\mathrm{kg} \mathrm{ha}^{-1}\right)$ & 1876 & 6.05 & 2.55 & 3.65 & 6.24 \\
$\mathrm{CV}(\%)$ & 36.65 & 16.29 & 14.22 & 22.16 & 6.65 \\
$\hat{\mathrm{r}}_{\mathrm{gg}}$ & 0.78 & 0.71 & 0.83 & 0.81 & 0.91 \\
$\mathrm{~h}^{2}(\%)$ & 0.61 & 0.51 & 0.69 & 0.65 & 0.82 \\
$\mathrm{~h}^{2} \mathrm{LL}$ & 0.38 & 0.21 & 0.5 & 0.44 & 0.71 \\
$\mathrm{~h}^{2} \mathrm{UL}$ & 0.74 & 0.67 & 0.79 & 0.77 & 0.89 \\
\hline
\end{tabular}


after inoculation favored the development of the fungus, leading to lower scores of the progenies. It was observed that in assessment of horizontal resistance, it is important to provide experimental conditions as similar as possible to normal crop conditions (Parlevliet 1981), excessive irrigation not being appropriate, preferentially using situations similar to those of commercial crops. The magnitudes of the heritabilities and of the coefficients of experimental precision obtained were similar to those observed in similar assessments (Carneiro et al. 2011), except for the coefficient of variation found in the 2010 dry season experiment. In carrying out this experiment, there was daily irrigation, leading to problems with weed management in the area, reducing the experimental precision.

The progenies were genetically heterogeneous $(\mathrm{P}<0.01)$ for grain yield, plant growth habit and grain type (Table 2 ). Experimental precision and estimates of genetic and phenotypic parameters were similar to those described in the literature (Takeda et al. 1991, Silva et al. 2006, Couto et al. 2008, Pereira et al. 2008, Marcondes et al. 2010, Carneiro et al. 2011).

It was observed that the correlations were not significant ( $p>5 \%$ ), indicating the possibility of absence of association between the traits assessed (Table 4). The negative, significant and undesired correlation between the "straw test" and grain type may be explained by the parents used in the cross. The sources of resistance used have grain types different from the carioca type, which was used as the standard for assessment of this trait. It is observed that the progenies that showed greater resistance to white mold may still have retained some alleles for the inferior carioca standard, derived from the donor parents, G122 or Ex Rico23. This occurred in spite of progenies with the carioca type derived from the recurrent parents having been selected. Nevertheless, the low value of the correlation, together with the fact that both traits are polygenic, indicates the possibility of identifying progenies with the ideal type of grain, together with greater resistance to white mold.

Significant correlation was found, indicating undesirable association between plant growth habit and reaction to white mold by the straw test, implying that genotypes that show better growth habit are more affected by the pathogen. However, their low value also indicates the possibility of selection of bushy and resistant genotypes, similar to the sources of resistance used.

The traits of "reaction to oxalic acid" and plant growth habit exhibited positive and significant correlation $(\mathrm{P}=0.07)$ and may collaborate towards obtaining superior genotypes that combine adequate growth habit and resistance to white mold. It is important to highlight the absence of correlation between oxalic acid $\mathrm{x}$ straw test. This result shows the possibility of the two methodologies for assessment of reaction to white mold measuring different mechanisms of reaction to the phytopathogen. In fact, plant resistance to oxalic acid consists of one of the first defense barriers to penetration of the pathogen (Cessna et al. 2000), while

Table 4. Phenotypic correlations between traits of agronomic interest

\begin{tabular}{llll}
\hline Trait I & Trait II & Correlation & Probability \\
\hline Yield & Growth Habit & 0.03 & 0.8074 \\
Yield & Grain type & -0.21 & 0.1464 \\
Yield & Oxalic acid & -0.06 & 0.6661 \\
Yield & Straw test & 0.14 & 0.6487 \\
Growth Habit & Grain type & 0.12 & 0.5887 \\
Growth Habit & Oxalic acid & 0.25 & 0.0765 \\
Growth Habit & Straw test & $-0.37^{* *}$ & 0.0083 \\
Grain type & Oxalic acid & 0.21 & 0.1370 \\
Grain type & Straw test & $-0.44^{* *}$ & 0.0015 \\
Straw test & Oxalic acid & -0.09 & 0.5378 \\
\hline
\end{tabular}

"Significant at $5 \%$; ** Significant at $1 \%$ by the "t" test.

Table 5. Gains from selection (GS) considering analysis of each trait in an isolated way by selection index composed of all the traits simultaneously and by selection index composed of assessment of reaction to white mold by "Oxalic acid" and "straw test" with selection intensity of $10 \%$

\begin{tabular}{llll}
\hline \multirow{2}{*}{ Trait } & In isolation & Simultaneously & White mold index \\
\cline { 2 - 4 } & GS (\%) & GS (\%) & GS (\%) \\
\hline Yield & 22.48 & 14.47 & 5.24 \\
Growth Habit & 7.12 & 4.04 & 0.13 \\
Grain type & 11.73 & 4.97 & -0.43 \\
Oxalic acid & 16.41 & 3.71 & 9.56 \\
Straw test & 17.36 & 2.39 & 12.08 \\
\hline
\end{tabular}


resistance to rotting of the tissues occurs after penetration and is probably due to the production of the proteins related to the pathogenesis, such as polyphenol oxidase (Cessna et al. 2000, Yang et al. 2007). Thus, obtaining progenies with high resistance, associating the two disease control mechanisms, may be achieved and it is desired. Among the genotypes assessed, progenies 17, 10, 89, 53 and 19 showed favorable results, considering the two methodologies of reaction to the pathogen.

It was observed that gains from selection proved to be greater for the selection performed for each trait in an isolated way (Table 5). However, as what is desired is obtaining cultivars that show a greater proportion of favorable alleles for diverse traits, selection based on the selection index composed by the rank sum of all the traits assessed simultaneously is most adequate.

When selection is performed based on the rank index

\section{REFERENCES}

Antonio RP, Santos JB, Souza TP and Caneiro FF (2008) Genetic control of the resistance of common beans to white mold using the reaction to oxalic acid. Genetics and Molecular Research 7: 733-740.

Carneiro FF, Santos JB, Gonçalves PRC, Antônio RP and Souza TP (2011) Genetics of common bean resistance to white mold. Crop Breeding and Applied Biotechnology 11: 165-173.

Cessna SG, Sears VE, Dickman MB and Low PS (2000) Oxalic Acid, a Pathogenicity Factor for Sclerotinia sclerotiorum, Suppresses the Oxidative Burst of the Host Plant. The Plant Cell 12: 2191-2199.

Collicchio E, Ramalho MAP and Abreu AFB (1997) Associação entre o porte da planta do feijoeiro e o tamanho dos grãos. Pesquisa Agropecuária Brasileira 32: 297-304.

Couto MA, Santos JB and Ferreira JL (2008) Melhoramento do feijoeiro comum com grão tipo carioca visando resistência à antracnose e à mancha angular. Ciência e Agrotecnologia 32: 1643-1648.

Huang HC, Mundel HH and Ericson RS (2003) Effect of physiological resistance and plant architecture on yield of dry bean under disease pressure of white mold (Sclerotinia sclerotiorum). Plant Protection Bulletin 45: 169-176.

Kim HS, Sneller CH and Diers BW (2000) Inheritance of partial resistance to Sclerotinia stem rot in soybean. Crop Science 40: 55-61.

Knapp SJ, Stoup WW and Ross WM (1985) Exact confidence intervals for heritability on a progeny mean basis. Crop Science 25: 192-194.

Kolkman JM and Kelly JD (2000) An indirect test using oxalate to determine physiological resistance to white mold in common bean. Crop Science 40: 281-285.

Kolkman JM and Kelly JD (2002) Agronomic traits affecting resistance to white mold in common bean. Crop Science 42: 693-699.

Kolkman JM and Kelly JD (2003) QTL conferring resistance and which considers only the reaction to white mold, the gains for these traits (straw test and oxalic acid absorption) are greater when compared to those obtained from selection based on the index considering all the traits assessed. However, the gains for yield and growth habit are reduced, while for grain type there is a negative gain from selection.

Thus, adopting a low selection intensity and considering the two indices, it may be observed that progenies 17, 19, 10 and 138 continued among the ten best for both indices. Highlights are progenies 10 and 19, which mainly associate the two mechanisms of resistance and commercially favorable grain type.

\section{ACKNOWLEDGMENTS}

To FAPEMIG for financial support and granting a scholarship to the first author.

avoidance to white mold in common bean. Crop Science 43: 539-548.

Marcondes EHK, Santos JB and Pereira HS (2010) Seleção de linhagens de feijoeiro com tipo de grão carioca e com os alelos co-4 e co-5 de resistência à antracnose. Ciência e Agrotecnologia 34: 975-982.

Menezes Júnior JAN, Ramalho MAP and Abreu AFB (2008) Seleção recorrente para três caracteres do feijoeiro. Bragantia 67: 833-838.

Miklas PN, Delorme R, Johnson WC and Gepts P (2001) QTL conditioning physiological resistance and avoidance to white mold dry bean. Crop Science 41: 309-315.

Mulamba NN and Mock JJ (1978) Improvement of yield potential of the Eto Blanco maize (Zea mays L.) population by breeding for plant traits. Egyptian Journal of Genetics and Cytology 7: 40-51.

Oliveira SHF (2005) Manejo do mofo branco. DBO Agrotecnologia 2: 8-13.

Parlevliet JE (1981) Disease resistance in plants and its consequences for plant breeding. In Frey JKP (ed.) Plant breeding II. Iowa State University Press, Ames, p. 309-364.

Pereira HS, Santos JB, Souza TP and Lima IA (2008) Seleção fenotípica e assistida por marcadores moleculares de famílias de feijoeirocomum com alta produtividade. Pesquisa Agropecuária Brasileira 43: $1551-1558$.

Petzoldt R and Dickson MH (1996) Straw test for resistance to white mold in beans. Annual Report of the Bean Improvement Cooperative 39: $142-143$.

Ramalho MAP, Ferreira DF and Oliveira AC (2012) Experimentação em genética e melhoramento de plantas. Editora UFLA, Lavras, 326p.

Resende MDV (2007) Matemática e estatística na análise de experimentos de campo. Editora Embrapa, Curitiba, 561p.

Silva MGM, Santos JB and Abreu AFB (2006) Seleção de famílias de feijoeiro resistente à antracnose e à mancha-angular. Pesquisa 
Agropecuária Brasileira 41: 1499-1506.

Singh SP, Terán H, Lema M, Schwartz HF and Miklas PN (2007) Registration of white mold resistant dry bean germplasm line A 195. Journal of Plant Registrations 1: 62-63.

Soule M, Porter L Medina J, Santana GP, Blair MW and Miklas PN (2011) Comparative QTL map for white mold resistance in common bean, and characterization of partial resistance in dry bean lines VA19 and
I9365-31. Crop Science 51: 12-139.

Takeda C, Santos JB and Ramalho MAP (1991) Progeny test for the "ESAL 501" x “A354" common bean (Phaseolus vulgaris L.) hybrid at different locations. Revista Brasileira de Genética 14: 771-779.

Yang B, Srivastava S, Deyholos MK and Kav NNV (2007) Transcriptional profiling of canola (Brassica napus L.) responses to the fungal pathogen Sclerotinia sclerotiorum. Plant Science 173: 156-171. 